\title{
Length-Weight Relationship, Abundance and Sex Ratio of the Giant River Prawn Macrobrachium vollenhovenii (Herklots, 1857) From River Osun, Southwestern Nigeria
}

Fafioye Oyebamiji O, Asiru Raheem $\mathbf{A}^{*}$ and Oladunjoye Rasheed $\mathbf{Y}$

Department of Zoology, Olabisi Onabanjo University, Ago-Iwoye, Nigeria

\begin{abstract}
Distribution, abundance, length-weight relationships of the African giant prawn (Macrobrachium Vollenhovenii) in River Osun was studied. Four hundred and fifty (450) samples were collected at 45 per week for 10 weeks between April and June 2016, at two different landing sites (Atan and Asejire Lake). Morphometric analysis showed that the prawn exhibited positive allometric growth (L-W) with regression equation "b" values of 4.869, 6.627 and 6.205 in Atan, Asejire and pooled samples respectively. The correlation between L-W was high; $r=0.580,0.834$ and 0.752 in Atan, Asejire and pooled samples respectively $(p<0.05)$. The sex ratio of $M$. vollenhovenii examined showed female dominance over male with ratio of 1.57:1.00 in Atan, 1.78:1.00 in Asejire and 1.74:1.00 in pooled samples. The rostral spines on the dorsal side of $M$. vollenhovenii observed ranged between 11-15 while on the ventral side was between 2 and 7. The condition factors obtained in Atan, Asejire and pooled samples are 2.09, 1.58 and 1.667 respectively. The length-weight relationships of $M$. vollenhovenii show relationships between lengths and weights which get plumper as they grow longer. The correlation coefficient " $r$ " indicated high correlation between length and weight. The samples were in good condition throughout the study period to depict that the environment as suitable for this prawn production.
\end{abstract}

Keywords: Giant African freshwater prawn; Macrobrachium vollenhovenii

\section{Introduction}

Prawn is a "decapod crustacean of the suborder Natantia" [1]. Freshwater prawns of the genus Macrobrachium constitute a group of economically important macroinvertebrate fauna. Found in most inland freshwater areas including ponds, lakes, rivers and irrigation ditches, as well as in estuarine areas [2]. Condition factor compares the well-being of a fish and is based on the hypothesis that heavier fish of a given length are in a better condition [3]. Condition factor has been used as an index of growth and feeding intensity [3,4]. Condition factor decreases with increase in length $[3,5]$ and also influences the reproductive cycle in fish and prawn. Incidentally, most studies on length weight relationship are on fishes from other water bodies $[3,6]$.

Length weight relationship of a prawn is basically a measure of the growth pattern or age. Growth is an important component of biological production, which affects overall production. Lengthweight relationships are important for a wide range of studies, such as estimating growth rates, age structure and prawn population dynamics [7]. Negative change in the growth rates may result in decreased individual health, reproductive success and increase risk of predation and mortality [8]. Variations of length-weight relationship is an indicator in fishes and crustaceans that reflects fluctuations of uptake and allocation of energy. Further variations are affected by many factors such as food, stress due to overcrowding or reproductive cycle.

Sex ratio is important information to characterize the population structure, to assist the calculation of reproductive potential and the estimate of the stock size of a given species [9]. It varied among sexes, species and seasons in both wild and cultured populations of $P$. monodon [10]. Length-weight relationship is studied to determine the growth and possible differences among different stocks of the same species [11]. This research was aimed at determining the sex ratio, abundance and length-weight relationship of prawns in River Osun in order to assess their condition factor (Figures 1-3).

\section{Materials and Methods}

\section{Description of the study area}

The Osun River flows southwards through central Yorubaland in southwestern Nigeria (Lat. $8^{\circ} 20^{\prime} \mathrm{N}$ and Lon. $5^{\circ} 16^{\prime} \mathrm{E}$ ) and meanders through three different States (Osun, Oyo, Ogun respectively) before Lagos State where it empties into the Lagos Lagoon and the Atlantic Gulf of Guinea (Lat. $6.56^{\circ} \mathrm{N}$ and Long. $4.06^{\circ} \mathrm{E}$ ) (https://en.wikipedia. org/wiki/Osun_river). It has length of about 166 miles and plays host to different diversity of fauna and flora including prawn. It is surrounded by green vegetation (trees and shrubs) along its course. Samples were collected at two different landing sites; Asejire in Oyo State and Atan in Ogun State. The two sites were selected based on their easy accessibility, relative availability of fishers and the prominence to their immediate community as fishing terminus (Figure 1).

\section{Prawn sample collection}

Four hundred and fifty (450) specimens were collected in all on weekly basis for 10 weeks between April and June 2016, at two different landing sites (Atan and Asejire Lake) with the assistance of artisanal fisher-folks. On each sampling, thirty specimens (30) and fifteen (15) specimens were collected randomly from Asejire and Atan respectively. The fisher folks used gill nets of various mesh sizes and fishing gears such

*Corresponding author: Asiru Raheem A, Department of Zoology, Olabis Onabanjo University, Ago-Iwoye, Nigeria, Tel: 08050400015; E-mail: asiruraheemadekunle@gmail.com

Received October 12, 2018; Accepted November 29, 2018; Published December 04, 2018

Citation: Oyebamiji OF, Raheem AA, Rasheed YO (2018) Length-Weight Relationship, Abundance and Sex Ratio of the Giant River Prawn Macrobrachium vollenhovenii (Herklots, 1857) From River Osun, Southwestern Nigeria. J Aquac Res Development 9: 554. doi: 10.4172/2155-9546.1000554

Copyright: @ 2018 Oyebamiji OF, et al. This is an open-access article distributed under the terms of the Creative Commons Attribution License, which permits unrestricted use, distribution, and reproduction in any medium, provided the original author and source are credited. 
Citation: Oyebamiji OF, Raheem AA, Rasheed YO (2018) Length-Weight Relationship, Abundance and Sex Ratio of the Giant River Prawn Macrobrachium vollenhovenii (Herklots, 1857) From River Osun, Southwestern Nigeria. J Aquac Res Development 9: 554. doi: 10.4172/2155-9546.1000554

Page 2 of 5

as baited non-return valve basket traps. Non-return valve traps were usually set at evening and recovered at morning of the following day because of their nocturnal behaviour. The specimens were immediately preserved in ice packed cooler and transferred to the laboratory, where they were examined for the research work (Figures 2 and 3).

\section{Identification of specimens}

Identification of specimens of Macrobrachium prawns collected was done to species level using diagnostic features described by FAO [12], Powel [13], and Marioghae [14] and through assistance of experts. The sex of each specimen was identified by visual observation of its morphological characteristics; male reproductive organ is located at the fifth pair of periopods, while female is located at the third pair [15]. In males, the base of the fifth pair of periopods approximates to the middle, while that of females is wide [16]

\section{Morpho-meristic data}

Length (L) of prawn specimens was measured from the tip of the telson to orbital notch in accordance with Abohweyere and Williams [17] to the nearest $0.01 \mathrm{~mm}$ using Vernier caliper and ruler for the large prawns, while small individuals were measured with fine-point dividers with the reading taken with ruler. Standard length was determined by taken measurement from the tip of the telson to the tip of the rostrum of the prawn, while total length (TL) was measured from the tip of the telson to the tip of longest chelate leg. Carapace length $(\mathrm{CL})$ was measured from posterior margin of orbit to posterior border of carapace in order to measure prawn size in accordance with Stephen. Carapace width (CW) was determined using Vernier caliper to measure the diameter from one side of the carapace to the other. Prawn pincer length (PL) is the measure of the length of the pincer from the base (coxa) to the tip of the pincer. Rostrum spines were carefully counted for both the dorsal (RSD) and ventral (RSV).
The prawn was weighed using digital weighing balance (Ohaus; Scout Pro Model SPU 402) to the nearest 0.01g after removal of excess water by air-dry, very small individuals were weighed on $\mathrm{H}-5$ balance. Damaged individuals with regenerating or otherwise anomalous limbs were discarded. For each location, the mean total length and weight as well as the standard error were calculated.

\section{Length-weight relationship}

Total length-weight relationship of M. vollenhovenii were calculated and represented by the equation [18]:

$\mathrm{W}=\mathrm{a}+\mathrm{bL}$ or $\mathrm{aL}^{\mathrm{b}}$

Where $\mathrm{W}$ is body weight (g),

$\mathrm{L}$ is length of the body in $(\mathrm{cm})$,

"a" is regression constant (Intercept) and;

"b" is regression coefficient (Slope).

The equation was then transformed into linear regression equation as:

$\log W=\log a+b \log L$

Degree of association between weight and length variables will be calculated by determination variables $(\mathrm{R})$. The correlation $\left(\mathrm{r}^{2}\right)$ is the degree of association between the length and weight was computed from the linear regression analysis: $\mathrm{R}=\mathrm{r}^{2}$

\section{Condition factor}

Condition factor is represented by $\mathrm{K}$ and was determined using the expression of Ricker,

\section{$\mathrm{K}=100 \mathrm{~W} / \mathrm{L}^{3}$}

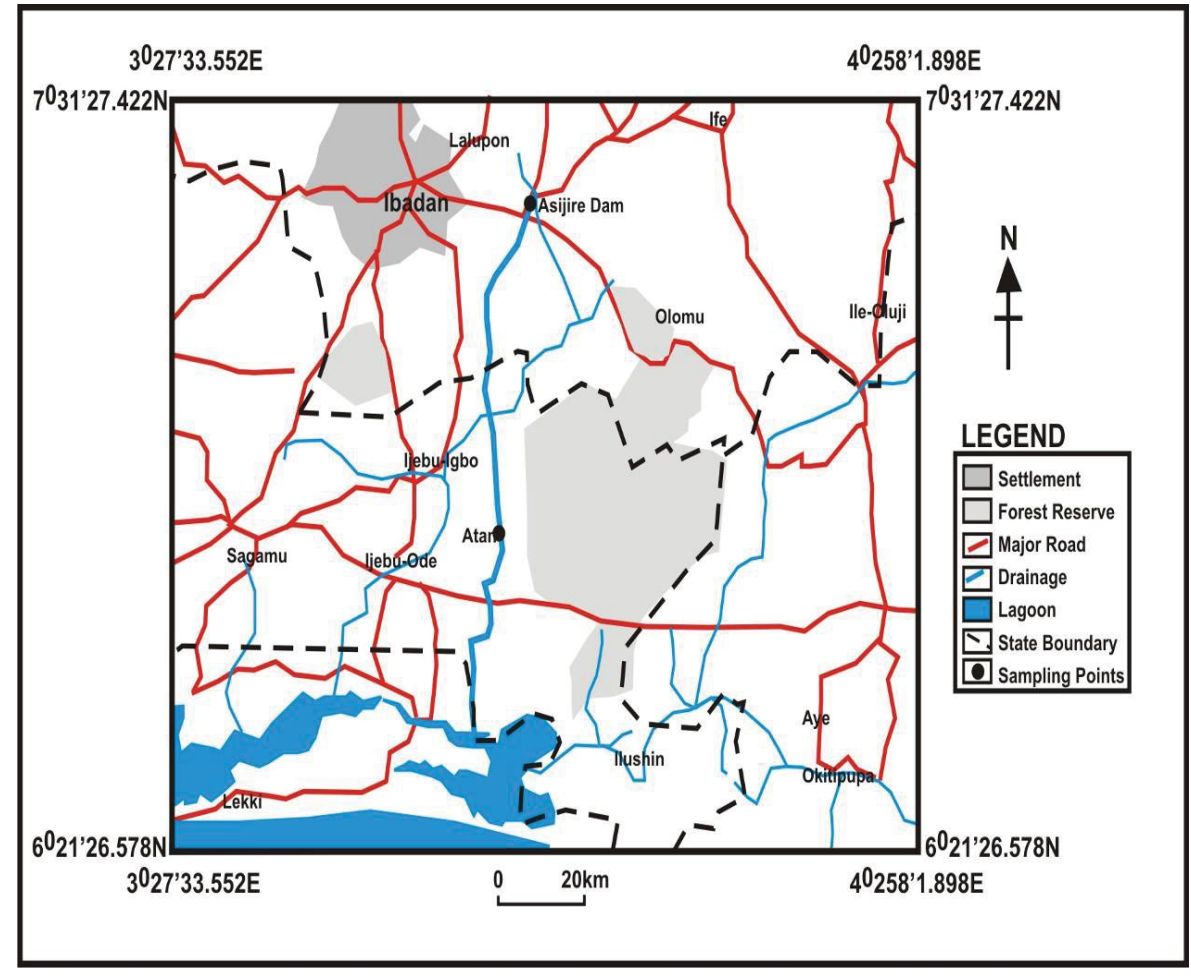

Figure 1: Map showing the study areas. 


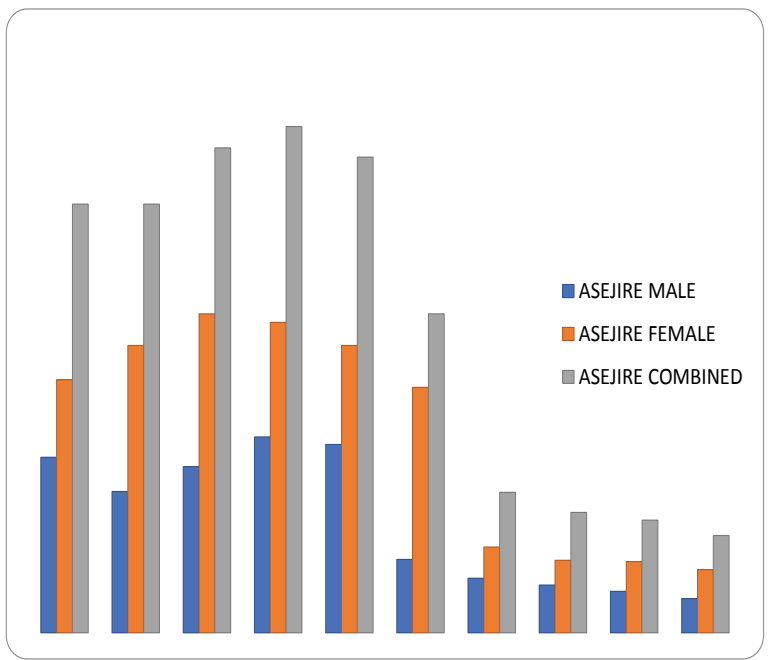

Figure 2: Abundance of prawn in River Osun.

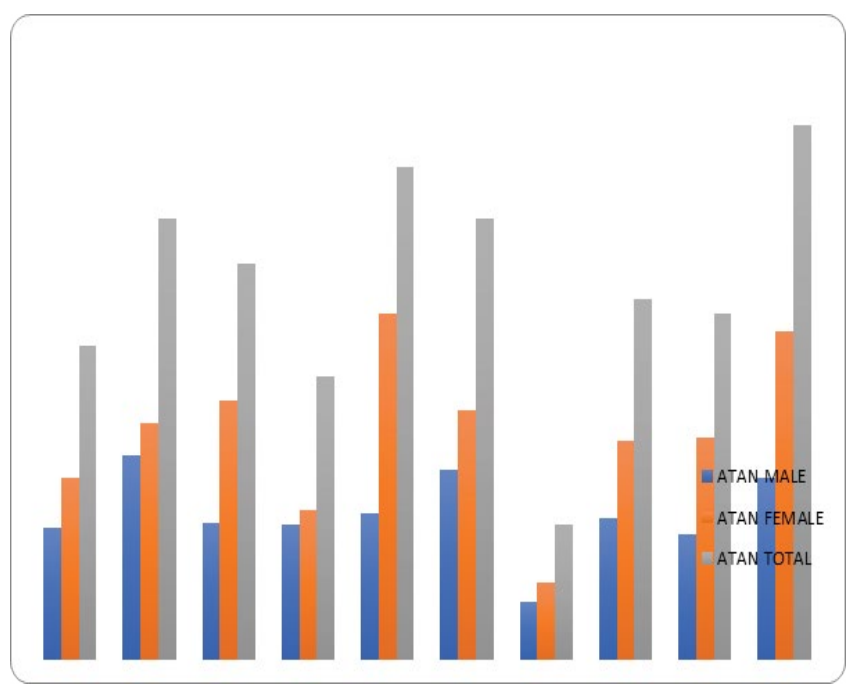

Figure 3: Sex ratio of prawns in River Osun

\begin{tabular}{|c|c|c|c|c|c|c|}
\hline \multirow{2}{*}{ Variables } & \multirow{2}{*}{ N Statistics } & \multirow{2}{*}{$\begin{array}{l}\text { Minimum } \\
\text { Statistics }\end{array}$} & \multirow{2}{*}{$\begin{array}{l}\text { Maximum } \\
\text { Statistics }\end{array}$} & \multicolumn{2}{|c|}{ Mean } & \multirow{2}{*}{$\begin{array}{c}\text { Std. } \\
\text { Deviation } \\
\text { Statistics }\end{array}$} \\
\hline & & & & Statistics & Std. Error & \\
\hline Weight & 150 & 9 & 106 & 30.41 & 1.050 & 12.861 \\
\hline SL & 150 & 5.3 & 18.0 & 9.861 & 0.1167 & 1.4295 \\
\hline $\mathrm{L}$ & 150 & 5.0 & 20.5 & 11.910 & 0.1258 & 1.5402 \\
\hline $\mathrm{TL}$ & 150 & 11.5 & 32.5 & 17.466 & 0.2206 & 2.7013 \\
\hline PLR & 150 & 5.9 & 19.7 & 8.551 & 0.1419 & 1.7377 \\
\hline PLL & 150 & 5.8 & 19.0 & 8.546 & 0.1342 & 1.6441 \\
\hline RSD & 150 & 12 & 15 & 13.05 & 0.066 & 0.805 \\
\hline RSV & 150 & 3 & 6 & 3.98 & 0.045 & 0.549 \\
\hline $\mathrm{CL}$ & 150 & 2.3 & 5.3 & 3.443 & 0.0369 & 0.4516 \\
\hline $\mathrm{CW}$ & 150 & 1.2 & 2.8 & 1.919 & 0.0180 & 0.2206 \\
\hline $\begin{array}{c}\text { Valid N } \\
\text { (list wise) }\end{array}$ & & & 150 & & & \\
\hline \multicolumn{7}{|c|}{$\begin{array}{l}\text { SL: Standard Length, L: Length, TL: Total Length, PLR: 2nd Periopod Length } \\
\text { Right } \\
\text { PLL: } 2^{\text {nd }} \text { Periopod Length Left, RSD: Dorsal Rostral Spine, RSV: Ventral Rostral } \\
\text { Spine } \\
\text { CL: Carapace Length, CW: Carapace Width }\end{array}$} \\
\hline
\end{tabular}

Table 1: Morphological features of Macrobrachium vollenhovenii in Atan.

\begin{tabular}{|c|c|c|c|c|c|c|}
\hline \multirow[b]{2}{*}{ Parameters } & \multirow[b]{2}{*}{ N Statistics } & \multirow{2}{*}{$\begin{array}{l}\text { Minimum } \\
\text { Statistics }\end{array}$} & \multirow{2}{*}{$\begin{array}{l}\text { Maximum } \\
\text { Statistics }\end{array}$} & \multicolumn{2}{|c|}{ Mean } & \multirow{2}{*}{$\begin{array}{c}\text { Std. } \\
\text { Deviation } \\
\text { Statistics }\end{array}$} \\
\hline & & & & Statistics & $\begin{array}{l}\text { Std. } \\
\text { Error }\end{array}$ & \\
\hline W & 300 & 8 & 89 & 22.34 & .646 & 11.189 \\
\hline SL & 300 & 6.8 & 14.0 & 9.437 & .0733 & 1.2695 \\
\hline $\mathrm{L}$ & 300 & 8.2 & 16.3 & 11.221 & .0813 & 1.4081 \\
\hline $\mathrm{TL}$ & 300 & 1.6 & 31.6 & 16.492 & .1819 & 3.1509 \\
\hline PLL & 300 & 4.6 & 18.4 & 8.225 & .1233 & 2.1316 \\
\hline PLR & 300 & 5.0 & 19.7 & 8.281 & .1246 & 2.1469 \\
\hline RSD & 300 & 11 & 15 & 12.99 & .044 & .761 \\
\hline RSV & 300 & 2 & 7 & 3.94 & .035 & .612 \\
\hline $\mathrm{CL}$ & 300 & .3 & 5.1 & 3.158 & .0321 & .5562 \\
\hline $\mathrm{CW}$ & 300 & 1.2 & 2.8 & 1.772 & .0160 & .2763 \\
\hline Valid N & 300 & & & & & \\
\hline
\end{tabular}

SL: Standard Length, L: Length, TL: Total Length, PLR: 2nd Periopod Length Right PLR: ${ }^{\text {nd }}$ Pincer's Length Left, RSD: Dorsal Rostral Spine, RSV: Ventral Rostral Spine CL: Carapace Length, CW: Carapace Width

Table 2: Morphological features of $M$. vollenhovenii in Asejire.

\begin{tabular}{|c|c|c|c|c|c|}
\hline No & Variable & $\mathbf{a}$ & $\mathbf{b}$ & $\mathbf{r}$ & $\mathbf{R}$ \\
\hline 450 & L-W & -46.478 & 6.205 & 0.752 & 0.546 \\
\hline 450 & L-SL & 0.387 & 0.803 & 0.892 & 0.796 \\
\hline 450 & L-CL & 0.199 & 0.267 & 0.735 & 0.540 \\
\hline 450 & L-CW & 0.203 & 0.141 & 0.785 & 0.617 \\
\hline 450 & SL-W & -35.976 & 6.369 & 0.690 & 0.476 \\
\hline 450 & SL-CL & 0.546 & 0.283 & 0.700 & 0.491 \\
\hline 450 & SL-CW & 0.408 & 0.148 & 0.737 & 0.544 \\
\hline 450 & SL-L & 1.952 & 0.992 & 0.892 & 0.796 \\
\hline 450 & CL-CW & 0.504 & 0.405 & 0.817 & 0.667 \\
\hline 450 & CL-W & -35.101 & 19.099 & 0.835 & 0.697 \\
\hline 450 & PLL-PLR & 0.505 & 0.946 & 0.927 & 0.859 \\
\hline
\end{tabular}

Key: A: Intercept, B: Slope, R: Coefficient of Regression, $\mathrm{R}^{2}$ : Coefficient of Determination, L: Length, W: Weight, SL: Standard Length, CL: Carapace Length, CW: Carapace Width, PLL: Left Pincer's Length, PLR: Right Pincers Length.

Table 3: Morphological relationships parameters and correlation values observed in $M$. vollenhovenii collected at both Atan and Asejire.

Where, $\mathrm{K}=$ condition factor,

$\mathrm{w}=$ the weight of prawn in grams

$\mathrm{L}=$ the total length of prawn in Centimetres

\section{Statistical analysis}

The statistical analysis of the data was carried out using Statistical Package for Social Sciences (SPSS 20). Regression analysis was used to determine the length-weight relationships while ANOVA test was used to ascertain difference in size classes and in locations while t-test was used to test for significant differences between male and female prawn.

\section{Results and Discussion}

\section{Distribution and abundance of prawns of River Osun}

Length - weight relationships

$$
\begin{array}{ll}
\text { Males: } \log \mathrm{W}=-52.259+6.813 \mathrm{x} & \left(\mathrm{n}=198, \mathrm{r}=0.774, \mathrm{r}^{2}=0.599\right) \\
\text { Females: } \log \mathrm{W}=-40.273+5.620 \mathrm{x} & \left(\mathrm{n}=252, \mathrm{r}=0.739, \mathrm{r}^{2}=0.546\right) \\
\text { Pooled: } \log \mathrm{W}=-46.49+6.205 \mathrm{x} & \left(\mathrm{n}=450, \mathrm{r}=0.752, \mathrm{r}^{2}=0.599\right)
\end{array}
$$

The parameters of length-weight relationships of $M$. vollenhovenii estimated in this study exhibited positive allometric growth with a "b" value of 6.205 with 6.369 in relation to standard length (SL) or ocular length. This result is in accordance with Jimoh et al., [19] who reported 
Citation: Oyebamiji OF, Raheem AA, Rasheed YO (2018) Length-Weight Relationship, Abundance and Sex Ratio of the Giant River Prawn Macrobrachium vollenhovenii (Herklots, 1857) From River Osun, Southwestern Nigeria. J Aquac Res Development 9: 554. doi: 10.4172/2155-9546.1000554

3.11 and 2.58 for M. vollenhovenii and M. microbrachion from Badagry creek by Jimoh et al., [18] who reported a "b" value of 6.32 for $M$. vollenhovenii from Anetekhai and Fagade [20] who observed that $M$. vollenhovenii from Asejire Lake exhibited positive allometry. On the separate of sex, male exhibited positive allometric growth with a " $b$ " value of 6.813 length-weight relationship and 5.254 'b' value SL-W relationship. While female also has allometric growth relationship of 5.620 and 7.464 from L-W and SL-W relationship respectively.

The length-weight (LW) relationships recorded in Atan and Asejire has a 'b' value of 4.869 and 6.627 respectively with 4.407 and 7.136 value from SL-W relationships. The difference in the two locations was as a result of nature of and the condition of locations; fishing activities in Atan was considerably low when compared with Asejire. This is logical as Prasad, [21] reported that length-weight relationships of a species could vary according to season and locality. The use of length to determine length-weight morphometric has been applied in prawns Mohanty et al., [22]. The growth rate of animals varied widely depending on so many factors such as availability of food, season of the year, stress, overcrowding, developmental stage or reproductive cycle. $M$. vollenhovenii exhibit allometric growth throughout the study which indicated that they are affected by one or more factors. According to Wootton [7], M. vollenhovenii became plumber as they grew larger.

It has been widely reported that $M$. vollenhovenii can attain the maximum length of $19.5 \mathrm{~cm} \mathrm{[12],} \mathrm{and} \mathrm{the} \mathrm{maximum} \mathrm{is} 20.5 \mathrm{~cm} \mathrm{(205}$ $\mathrm{mm}$ ) from a sample from Atan. This shows relative undisturbed nature of Atan. The correlation value " $r$ " obtained from relationship between length and weight relationship is $0.58,0.83$ and 0.75 from Atan, Asejire and pooled accordingly. This value is said to be positively high [19] and Arimoro [23] recorded a positive correlation 0.95 and 0.84 respectively between total length and body (Tables 1 and 2).

M. vollenhovenii is one of the largest species of Macrobrachium known, the mean length in $M$. vollenhovenii in Atan, Asejire and pooled were $11.91 \mathrm{~cm}, 11.22 \mathrm{~cm}$ and $11.450 \mathrm{~cm}$ and body weight of $30.40 \mathrm{~g}, 22.34 \mathrm{~g}$ and $25.03 \mathrm{~g}$ respectively is more than $8.06 \mathrm{~cm}$ and 6.29 g reported by Jimoh et al., [19], who reported mean length of $18.7 \mathrm{~g}$ and relatively low compared to $14.94 \mathrm{~cm}$ and $77.86 \mathrm{~g}$ in male reported and $13.25 \mathrm{~cm}$ and $47.27 \mathrm{~g}$ by Anetekhai [24]. The relatively low weight and length compared to Anetekhai [24] might be due to period of the year the data was obtained as the researcher was told by the fishermen that the biggest samples of $M$. vollenhovenii are usually caught during their breeding season which is usually during the month of July to September. This period coincides with the period of abundant food in the water environment (Table 3 ).

According to Murphy and Austin, meristic features such as rostrum spine, teeth, morphology of the chelipeds, palm and fingers have been viewed as useful diagnostic taxonomic character in prawns. The rostrum spines observed in this study from the study centres showed that the dorsal spines are considerably more than the ventral spines with mean of 13.05, 12.99 and 13.01 (dorsal) and 3.98, 3.94 and 3.96 from Atan, Asejire and pooled respectively.

On the dorsal side, 13 spines have the highest occurrence with 53.3\% in Atan, Asejire and pooled while on the ventral side, 4 had the highest frequency of occurrence with $74 \%, 72 \%$ and $73.1 \%$ from Atan, Asejire and pooled respectively. This result is slightly different from 5 ventral spines and 9 highest dorsal spines recorded by Jimoh et al. [19].

The sex ratio observed during the present study revealed that the females were significantly more than the males. This corroborates with the report of Jimoh et al. [18] in M. Vollenhovenii. This observation is in contrast to the reports of Inyang [25], Marioghae [13,26], Meye and Arimoro [1] and Marioghae and Ayinla [27], where the sex ratio was fairly distributed and male dominance over female as reported by Nwangi. This finding shows that female proportion to male was higher which was similar to the findings of Anetekhai, [28] who reported a sex ratio of male to female (1:3) from Asejire Lake but considerably lower than 1:5 reported by Sagua [29] in Paleamon hastatus.

Sex ratio variation observed may be due factors such as maturity stage, matured male is stronger and protect them more. The females may also be more prone or vulnerable to catch in nature than males who migrate into deeper water soon after spawning. Larger population of female than male could have also resulted from physiological response to overfishing. In having more females will aid continuity of life and protect the species from going into extinction. A male is actually enough for several females to facilitate reproduction. Male dominance depicts threats to population in a particular area.

\section{Conclusion}

In conclusion, $M$. vollenhovenii dominates River Osun. They were widely distributed throughout the study area and are in abundance. The length - weight relationships of $M$. vollenhovenii showed relationships between lengths and weights and that they get plumper as they grow longer. The high correlation coefficient " $\mathrm{r}$ " shows there was high correlation between length and weight. Despite the stress and prone to overfishing, the samples are still in good condition throughout the study period which depicts that the environment is suitable for this species found during this period.

\section{References}

1. Meye JA, Arimoro FO (2005) Aspects of the ecology, reproductive and growth characteristics of Macrobrachium dux (Lenz, 1910) (Crustacea; Decapoda; Natantia) in Orogodo River, Niger Delta, Nigeria. Eur J Sci Res 2: 585-596.

2. New MB (2002) Farming freshwater prawns; A Manual for the Culture of the Giant River Prawn (Macrobrachium rosenbergii). Food and Agriculture Organization, Marlow, UK. p: 212

3. Abowei JFN, George ADI (2009) A study of the length - weight relationship and condition factor of Callinectes amicola (De Rochebrune, 1883) from Okpoka Creek, Niger Delta, Nigeria. Int J Anim Vet. Adv 1(2): 66-72.

4. Fagade SO (1979) Observation of the biology of two species of Tilapia from the Lagos lagoon Nigeria. Bull Inst Fond Afr Nore Ser A 41: 627-658.

5. Abowei JFN (2010a) The condition factor, length - weight relationship and abundance of llisha Africana (Block, 1795) from Nkoro River Niger Delta, Nigeria. Adv J Food Sci Technol 2: 6-11.

6. Abowei JN, (2010b) The condition factor, length-weight relationship and abundance of Elops seneganensis (Regan, 1909) from Nkoro River, Niger Delta, Nigeria. Adv J Food Sci Technol 2: 16-21.

7. Tsoumani M, Liasko R, Moutsaki P, Kagalou I, Leonardos I (2006) Lengthweight relationship of an invasive cyprinid fish (Carassius gibelio) from 12 Greek lakes in relation to their trophic states. J Appl Ichthyol 22: 281-284.

8. Wootton RJ (1992) Fish ecology; Tertiary level biology. Blackie Publication, London, UK. p: 212.

9. Vazzoler AEAM (1996) Biologia da reprodução de peixes Teleósteos; teoria e prática. Brasília; CNPQ; Nupélia.

10. Primavera JH, Parado-Estepa FD, Lebata JL (1998) Morphometric relationship of length and weight of giant tiger prawn Penaeus monodon according to life stage, sex and source. Aquaculture 164: 67-75.

11. King M (2007) Fisheries biology, assessment and management. (2nd edn). Blackwell Scientific Publications, Oxford, UK. pp: 1-381.

12. Holthius LB (1980) Prawns and prawns of the world. An annotated catalogue species of interest to fisheries, FAO Fish Synopsis FAO Species Catalogues. 125: 1-261. 
Citation: Oyebamiji OF, Raheem AA, Rasheed YO (2018) Length-Weight Relationship, Abundance and Sex Ratio of the Giant River Prawn Macrobrachium vollenhovenii (Herklots, 1857) From River Osun, Southwestern Nigeria. J Aquac Res Development 9: 554. doi: 10.4172/2155-9546.1000554

Page 5 of 5

13. Powell CB (1983) Fresh and brackish water prawns of economic importance in the Niger Delta.In Proceedings of the $2^{\text {nd }}$ Annual Conference of the Fisheries Society of Nigeria. Nigeria. pp: $254-285$

14. Marioghae IE (1982) Notes on the biology and distribution of Macrobrachium vollenhovenii and Macrobrachium macrobrachion in the Lagos Lagoon. Rev Zool Afr 96: 493-508.

15. Hart Al, Ansa EJ, Sekibo I (2003) Sex ratio, Sexual dimorphism and fecundity in pond reared Niger River prawn, Macrobrachium felicinum (Holthius 1949). The Zoologist 2: 56-61.

16. Tonbarapagha KH, Ebere SE (2013) Reproductive Biology of African River Prawn Macrobrachium vollenhovenii (Crustacea, Palaemonidae) In the Lower Taylor Creek, Niger Delta, Nigeria. Ecologia balkanica 5: 49-56.

17. Abohweyere PO, Williams AB (2008) Length-weight relationship and condition of Macrobrachuim macrobrachuim in the Lagos - Lekki Lagoon system, Nigeria. Res J Biological Sci 3: 1333-1336

18. Jimoh AA, Fakoya KA, Hammed AM, Amosu AO, Kumolu-Johnson CA (2005) Meristics and morphometrics in the African river prawn, Macrobrachium vollenhoveni (Herklots, 1857) from Ologe Lagoon, Southwest Nigeria. J Agric Environ Res Stud 1: 12-18.

19. Jimoh AA, Clarke EO, Whenu OO, Anetekhai MA, Ndimele PE (2012) Morphological Characterization of Populations of Macrobrachium vollenhoven and Macrobrachium macrobrachion from Badagry Creek, Southwest Nigeria. Asian J Biol Sci 5: 126-137.

20. Anetekhai MA, Fagade SO (1989) Age, growth and moulting in Macrobrachium vollenhovenii from Asejire Lake, Ibadan, Oyo State, Nigeria. J Expt Appl Bio 1: $70-82$.

21. Prasad G (2001) Length-weight relationships of Penaeus monodon reared in semi-intensive culture systems of Kerala, India. Naga. The ICLARM Quarterly 24: $16-17$

22. Kumari MS, Sucharita MS, Dash Bisnu P, Debansu Sekhar P (2013) LengthWeight Relationship and Condition Factor of Penaeus monodon Fabricius, 1798 in Northern Odisha, India. Int J Sci Res 4: 2319-7064.

23. Arimoro FO, Meye JA (2007) Some aspect of the biology of Macrobrachium dux (lenz, 1910) (Crustacea; Decapoda; Natantia) in River Orogodo, Niger Delta, Nigeria. Department of Zoology, Delta State University. P.M.B 1, Abraka, Nigeria. Acta boil colomb 12: 111-122.

24. Anetekhai MA (1997) Moulting, meristics and morphometric in the African river prawn, Macrobrachium vollenhovenii (Herklots, 1857), from Asejire Lake, Oyo State, Nigeria. J Prospects Sci 1: 110-114

25. Inyang NM (1981) On the biology of Macrobrachium felicinum (Holthius) in the lower Niger River of Southern Nigeria. Rev Zool Afr 98: 440-449.

26. Marioghae IE (1990) Studies on fishing methods, gear and marketing of Macrobrachium in the Lagos area. Nigerian Institute for Oceanography and Marine Research (NIOMR), Lagos, Nigeria. p: 20.

27. Marioghae IE, Ayinla OA (1995) The reproductive biology and culture of Macrobrachium vollenhovenii (Herklots, 1857) and Macrobrachium macrobrachion (Herklots, 1851) in Nigeria. Niger Inste Oceanog Mar Res 100: 16

28. Anetekhai MA (1990) Sexual dimorphism and egg production in the African river prawn, Macrobrachium vollenhovenii (Herklots), from Asejire Lake, Oyo State, Nigeria. Niger J Sci 24: 147-151.

29. Sagua VO (1980) Observations on the ecology and some aspects of reproductive biology of the small white prawn Palaemon hastatus Aurivillius (Crustacea; Palaemonidae) in the Lagos area of Nigeria. Bull. Inst Fundam Afr Noire Ser A 42: 279-295. 